\title{
THE IMPLEMENTATION OF NATIONAL EXAMINATION AS THE DIRECTION OF NATIONAL EDUCATION POLICY
}

\author{
Rijal Firdaos ${ }^{1}$ Ahmad $^{2}$ \\ rijalfirdaos@radenintan.ac.id, ahmad@radenintan.ac.id \\ ${ }^{1,2}$ Universitas Islam Negeri Raden Intan Lampung
}

\begin{abstract}
This study aims to find out how the implementation of the UN can be used as a continues policy material. This research is a literary research where researchers trace the literature related to the implementation of the $U N$ and the direction of educational policy. The results of this study indicate that the implementation of the UN is still needed but with some notes. All supporting components and instruments must be ready and evenly distributed throughout the districts or cities that deal with the competence of teachers, supporting facilities, and public awareness of the importance of the quality of education. The National Exam encourages all parties to work hard in order to achieve better learning outcomes for learners, in accordance with the competency standards of graduates. UN has become a part of the national policy direction, which gave birth to the National-Standard School Examination, the curriculum changes from KTSP to K13, and the implementation of the Full Day School program as an effort to maximize the potential of learners in school activities.
\end{abstract}

Keywords: National Examination; implementation; national education policy

\section{INTRODUCTION}

The national development in the field of education is the effort to improve the life of the nation, and to improve the quality of Indonesian in realizing a progressive, just, and prosperous society, and enabling its citizens to develop themselves, both with regard to the physical and spiritual aspects based on Pancasila and the 1945 Constitution. National education's function is to develop capabilities and to improve the quality of life and dignity in order to realize the goal of national education (Soedijarto, 2000). As a step towards creating such progress, the government always strives to initiate various programs related to improving the quality of education both in the learning process and in the evaluation system. This is aimed at addressing the low quality of education (Hayat, 2006).

According to (Suwandi, 2013) in determining programs to improve the quality of education, it requires information on the quality of education at a certain time and the performance of the administrators of education. This information is obtained through the evaluation of educational programs that have been implemented so far. One of the objectives of evaluation in the field of education is to know the development of 
students' learning outcomes and teachers' teaching outcomes. The results of this evaluation are then followed up in the form of education quality improvement programs.

As we know, the final evaluation system that has been tested by the term of National Examination $(U N)$ which has been implemented in recent years seems to have become part of the national final evaluation. Although there is still controversy about its existence, the government apparently has determined to set the UN as an assessment instrument. UN as a policy is an application of Law No: 20 of 2003 on National Education System, especially article 57 paragraph (1): Evaluation is done in the framework of national quality control of education ..."Furthermore, in paragraph (2) it is mentioned: " Evaluation done to learners, institutions, and educational programs on the formal path ... "Then, article 58 paragraph (1) is mentioned: "Evaluation of learners' learning outcomes conducted by educators to ...". Theoretically, UN is a measurement and assessment of the competence of students nationally at the level of primary and secondary education. From the policy point, (Supa'at, 2013) expresses the purpose of $U N$, among others, is to measure the achievement and competence of graduates nationally on certain subjects in the science and technology subject group and to map the level of achievement of students' learning outcomes at the school and local level.

The existence of controversy is caused by the imperfection in the pattern measurements in each region. The measuring tool in the national dimension may not be relevant when it is compared with the contents of the material that exists in certain areas. In the Java island itself, there are some schools that are far from accessing the advanced class communication technology, which is not directly proportional to the implementation of the UN. The phenomenon in the field, most of the next generation of the nation whose status as students at their final year of study feel objected to the government policies that increase the standard of National Examination $(U N)$. Of course, they are upset because they are afraid of not passing if the standard of graduation is used. This panic is not only felt by the students at the end of their study, it is also felt $\mathrm{b}$ the administrators of the schools including the principles and the teachers. They could not imagine what would happen if many of their school students could not pass. The sense of shame will fall into the schools and their members because the parents are not wise enough to be included as the cause of this failure. Then supposedly 
there are those school managements who are trying to design the team to success the examination in undignified ways. Parents as the stakeholders are wary of this situation. Not a few of those who prepare an unlawful strategy or shortcuts to help their children to pass.

However, whatever the circumstances, in an effort to improve the program, the sustainability of the $U N$ should be guarded with a myriad of assessments. In this case is an evaluation. Ralph Tayler (1950) defines evaluation as the process of collecting data to determine the extent to which, in what way, and which parts of educational objectives have been achieved. If not, how and why. While Cronbach and Stufflebeam as quoted by (Arikunto, 2002) add evaluation is not just measuring the extent to which goals are achieved but also used to make decisions.

Higher education finally must continue to play its part in creating, preserving and passing on knowledge at the highest levels. Institutions of higher education also play a decisive part in rethinking education, as regards both where and when it takes places (Delors, 2013). Based on the opinions of the experts, the government can practically collect some data that must be answered, as a remedy for satisfactory outcomes. Good data on input, transformation, and output its. Or at least, the inventory of data in the form of a classification of questions' quality level in each region with standardized indicators, as well as the provision of appropriate scoring scale.

Assessment is one of the activities undertaken to measure and assess the level of attainment of the curriculum. Assessment is used to determine the strengths and weaknesses that exist in the learning processes, which can be used as a basis for decision making. Assessment can also be used as a process to conclude and interpret facts as a professional basic consideration to take the policy to collect information about learners, said (Surapranata, 2004).

The development of the current concept of educational assessment suggests a broader direction. The concept generally revolves around the following views:

a. Assessment is not only directed to established educational goals, but it also contains hidden goals, including possible side effects.

b. Assessment is not only done through the measurement of students' behavior, but also the assessment of the components of education, namely input, process, and output. 
c. Assessment is not only meant to know whether or not the goals are being achieved, but also to find out whether they are important to learners and how learners achieve them.

d. Considering the extent of objectives and assessment objects, the tools used in the assessment are very diverse, not only fixated on mere tests but also non-test assessments, according to (Sudjana, 2005).

In reality, it seems that the $U N$ has not been able to follow the ideal concept initiated by the assessment experts. The $U N$ has not been proven to contribute constructively to the outcome. Learners who want to continue their education at higher educational institutions are still obliged to take entrance tests. The score gained in $U N$ does not become a barometer of one's reliability and competence. In fact, bad history in the implementation of the $U N$ has made learners, teachers, principals, parents, and other stakeholders to be concerned. For some others, the $U N$ served as a frightening thing. These data, followed by several cases of depression of learners and even more extreme cases are the suicide due to excessive anxiety in the $U N$.

Seeing this phenomenon, (Soedijarto, 2008) considers that the $U N$ should not be done, like America and Germany that do not apply it for the final evaluation. However, the preferred policy is to help learners optimally, by (1) providing professional teachers, whose whole time is devoted to becoming educators; (2) provide school facilities that enable learners to learn joyfully with adequate sport, recreation, and teachers' workspace; (3) provide rich learning media, which enables learners to continuously learn by reading compulsory books, reference books, and reading books (including novels), as well as the completeness of laboratories and libraries, enabling learners to learn up to the level of learning enjoyment; (4) continuous, comprehensive, and objective evaluation.

Many studies have been conducted on the National Examination including (Asiah \& Rofieq, 2011), namely analysis the national exam policy at the Vocational High School (SMK) level. Academic integrity and academic anxiety in facing the National Examination for Students (Firmantyo \& Alsa, 2016), the all-time National Examination controversy (Silverius, 2010), National Examination as a mirror of education quality and unifying the nation (Safari, 2015), evaluating the application of final school examinations based on national standards (Mardapi, 2009), evaluation of the 
implementation of the National Standard School Final Examination (UASBN) (Suwandi, 2013). A study by (Ghofur, 2014) eliminated by changing the concept of the implementation of National Examination, namely by eliminating the graduation requirements taken from the $U N$ results. $U N$ results are only used as a mapping of the quality of education, not to be a graduation requirement. Research by (Sulistyo, 2007) with the results that expectations, challenges, and opportunities for $U N$ actually still exist, and the National Examination should be viewed with a positive attitude and optimism to further spur the regions to move forward in the corridors of national development signs, not baseless defensive attitudes. That was done while making technical improvements to the National Examination as a testing system. The study (Nasution, 2016) related to exploring the potential of national examinations, whatever government policy to improve the quality of workforce according to the demands of the times depends on how the potential of the National Examination can be explored. The government must continue to try to find patterns and models so that the $U N$ does not waste the government budget every year in vain. $U N$ have enormous potential to develop the nation, but if mismanagement will potentially degrade the nation in the global competitive arena. Research by (Hidayah, 2013) regarding national examinations in the perspective of public policy.

From the introduction above, the author tries to identify some of the problems to be solved, as a step effort to evaluate the implementation of $U N$ program, towards the improvement of a proportional final stage evaluation system.

\section{THE RESULT OF THE RESEARCH AND THE DISCUSSION}

Before the author discusses how the final evaluation system is relevant, which is able to make learners have the competence in accordance with its potential, allow the author to start with the support of existing concepts and theories.

\section{Measurement, Assessment, and Evaluation}

In the process of learning, there are at least three terms that are interconnected with each other, which sometimes some of us are still mistaken in understanding it, even considering it the same. The three terms are measurement, assessment, and evaluation. Measurement is a measuring activity, by comparing something using a certain measurement, for example measuring body temperature with a thermometer, measuring 
water with a hydrometer, etc. Another example; of the 100 items asked in the test, Ridwan was able to answer 80 items. From this example, we can understand that the measurement is quantitative.

Assessment is the activity of judging by taking a decision on something using the good and bad criteria qualitatively. Based on the previous example, Ridwan was able to answer 80 items, it can be concluded that Ridwan is categorized as intelligent children. According to (Jamaris, 2010), assessment is a process done in systematic activities in order to collect information about something, such as about child development and learning progress.

National examination is basically an evaluation of the achievement of educational programs. Evaluation is an activity to know the achievement of a program. Evaluation provides information for the policy in two ways. The first, evaluation provides information for policymakers about the state of education or learning achievement of a particular group. Second, evaluation's information is used as an administrative tool for implementing policies.

The evaluation covers both steps, measuring and assessing. The first definition developed by Ralph Tyler (1950) in Suharsimi, that states evaluation is a process of collecting data to determine the extent to which, in what way, and which part of educational objectives has been achieved. If not, which part and why (Arikunto, 2002). However, there is no denying that the evaluation in the field of education, especially the evaluation of the learners' learning achievements, is largely derived from measurement results (Sudijono, 2005).

1. Role and Purpose of Evaluation

According to (Tayibnapis, 2000) formally, evaluation has played an important role in education, among others to (a) make policies and decisions, (b) assess the learners' learning outcome, (c) assess the curriculum, (d) give trust to schools, (e) monitor the given funds, and (f) improve educational materials and programs.

The roles and objectives of the evaluation, when linked with the school's activity program, can at least provide information to all existing stakeholders, which can then be used as a means of conducting evaluation activities.

2. Objectives and Usability Assessment 
The assessments made by teachers basically aim to: (a) get feedback, (b) find out students' achievement, (c) put students in teaching and learning situations, d), recognize the students' background (psychological, physical and environmental). The four objectives and usefulness are very important for the teacher to know as an evaluator, which continuously assesses both the learning process and learning outcomes.

3. Assessment Principles

In realizing ideal assessment activities, each teacher must recognize the following principles of assessment:

a. Principles of Conformity (objectivity)

Each assessment must be in accordance with the objectives to be achieved. The information obtained should be as up to date as possible. Thus, the test that becomes the measuring device must be carefully arranged and given at the right time. The principle of conformity can be implemented by answering three questions as follows: what is the purpose of conducting an evaluation, when the evaluation should be implemented, and how the evaluation should fit the purpose.

b. Principles of Continuity (Continuity)

Evaluation should be continuous, following the students' progress from time to time. Existing information is always supplemented with new information. The more often the evaluation is done, the more information it gets, the better the students are known, and the more accurate the decisions are made. c. Overall Principle (Integrity)

(Buchori, 2006) states that an evaluation should take into account all aspects of students' development. Therefore, evaluation should be comprehensively integrated into learning achievements, attitudes, behavior, interests, ambitions, trends, environment, physical abnormalities, etc.

From the above conceptual approaches, we can analyze that micro-education through the implementation of learning in schools can be partially assessed through selfassessment, self-evaluation, and achievement targets. In this case, schools and teachers know more clearly the condition of learners. Thus, even the final stage of assessment and evaluation can actually be carried out through each school, with reference to 
standard competences, basic competencies, and indicators, nationally outlined through curriculum objectives.

A good late-stage evaluation can actually be done by each school unit or regional from each region, with reference to a standardized evaluation system. That is, to know the learners' development can be done through the National Examination, however, the $U N$ is not a determinant of graduation, but only a barometer of each learner's ability. Because according to (Mardapi, 2009) National examination is basically an evaluation of the achievement of educational programs. Evaluation is an activity to know the achievement of a program. Evaluation provides information for the policy in two ways. The first evaluation provides information for policymakers about the state of education or learning achievement of a particular group. Second, evaluation information is used as an administrative tool for implementing policies.

How is the implementation of the National Examination policy that has been going on?

\section{Policy Evaluation}

There are many definitions of policy concepts. (Dye, 1978) imposes restrictions on policy as "... whatever the government is trying to do or does not do." 1 (Hofferbert, 1974) defines as "... the visible products of decisions taken by the figures to identify themselves with the societal ideals."

The policy is etymologically taken from the Greek language, namely "polis" which means city (city). Policy refers to the ways in which all parts of the government directly to manage their activities. Abidin (2006), as quoted by Syafaruddin, says that the policy is a governmental decree that is general and applicable to all members of society. According to Nichols (1977), the policy is a conscientious and careful decision by top decision-makers and not repetitive and routine activities that are programmed or related to decision rules, (Syafaruddin, 2008).

Based on the above opinion, the policy means a set of goals, principles, and rules that guide an organization. The policy covers the entire organization's guidance. In other words, the policy is the result of a carefully crafted top management decision that is the purpose, principles, and rules that lead the organization into the future.

The definition of education policy is a formulation of a variety of ways to achieve national education goals. The achievement of the two constitutional messages 
for national education is outlined in various education policies. These educational policies are planned to be realized or achieved through social institutions or social organizations in the form of formal, non-formal, and informal institutions, in (Tilaar, 2009). Since 1968 in the framework of national development, the Indonesian government has designed and implemented various policies, programs, and projects to develop various sectors of life. As an activity, can the result be seen immediately after the implementation and some cannot; some succeeded and others failed. Part of the project only takes place within a certain time and some must be extended or applied in other areas, according to (Wirawan, 2004).

To find out if a policy, program, or project is successful or failing or to determine whether it should be discontinued, extended, or implemented in other areas, information on the performance of such policies, programs, and projects is required. Thus, its performance should be measured based on the objectives to be achieved. Has the policy reached its objectives at the appointed time, are the resources provided for implementing the policy have been used in accordance with the terms of its use?

There are three policy processes, namely; Formulation, implementation, and evaluation. Policymaking in government includes political activity. In this context, political activity is described as a visualization process of policymaking. The political activity consists of a series of interdependent and arranged phases of time, agenda setting, policy formulation, policy adoption, policy implementation, and policy assessment.

According to (Syafaruddin, 2008), the formulation of the policy contains some important contents that serve as guidelines for action. The policy content includes: (a) interests affected by the policy, (b) the type of benefits to be generated, (c) the degree of desired change, (d) the position of the policy maker, (e) who the program implementer, and lastly (f) the resources. Further, according to (Syafaruddin, 2008) in the context of its implementation, the policy contains: (a) the powers, interests, and strategies of implementers involved, (b) the characteristics of institutions and authorities, (c) compliance and responsiveness, and (d) in the business context, policy formulation can be realized in various forms of decision fields and alternative purposes. A policy should not be left alone after it is implemented. As soon as the implementation of the policy 
takes place, it is necessary to be examined as the management process, as well as the necessary controls as a process of policy stabilization or evaluation.

Joseph Fischer: states "Educational institutions cannot be understood apart from the total political atmospheres in which they arise". The role of the State cannot be separated in the educational process. Various educational experts have discussed this issue since Plato as well as educational experts in the modern countries. Michael W Apple (1995) as quoted by (Tilaar, 2009) claims that the State is a unit based on power. In an effort to preserve its power, the State has made education as a mean of achieving that goal. Similarly as the citizenship life (Tilaar, 2009), in the preservation of state's power through cultural politics, Apple also adds that the cultural politics of a State is channeled through its educational institutions.

The purpose of evaluation as a way of making decisions is; that the assessment process that has been used as a reference, should be able to underlie the birth of national policy toward the existence of the $U N$ for the next period. In this case, if the $U N$ is considered relevant, then such a system can still be used as a form of evaluation of final learning outcomes. But if it is considered failed, or has not reached the maximum target desired, then the government is entitled to provide decisions by using a new and better $U N$ replacement. Or, back to the previous evaluation system, the final Evaluation stage (Ebtanas), which measures students' ability, without making it a graduation requirement.

\section{National Exam as an Achievement}

Indeed, the implementation of the $U N$ is, in fact, encouraging all parties concerned to work better. Based on the results of several studies, it can be concluded that the $U N$ can encourage students to study more diligently, encourage teachers to teach better, encourage school principals to pay more attention to the quality of education in schools, and encourage parents to pay attention to children's' learning (Mardapi, 2009). This has a direct impact on the students' learning outcomes achievement towards improving the quality of education at the regional and national level.

Therefore, the improvement of the quality of education is an urgent demand and non-negotiable, in order to improve the quality of Human Resources (HR), 
communities, and nations to have qualified human resources. With this, our nation will be ready to compete in the job market and global relation.

From the perspective of educational equity, the $U N$ can actually be used as a way to map the quality of education. Based on the results of the existing $U N$, it can actually be used as tools to identify schools and areas that have good educational quality as well as schools and areas that are still less qualify. The government certainly can foster and help the school and proportionally in order to increase and equitable education quality throughout the country. As a result, quality education is not only found in big cities and not only can be enjoyed by a few people with a strong economy but spread evenly throughout the country and can be enjoyed by all people, (Zakaria, 2004).

The research result of Ki Supriyoko (2004) as quoted by Zakaria, from Lembaga Studi Pembangunan Indonesia also showed similar findings, that the $U N$ is needed for the improvement and equality of education in Indonesia. In addition, the findings of this study also show that although there are some citizens who disagree with the $U N$, most of the community members, including educators of various types and levels of education, regard the $U N$ as necessary and expect it to be implemented continuously.

In the historical perspective, since the declaration of Indonesian independence, State Exam, which is national in nature, had been implemented, up to the early seventies. In the era of State Exam, there is a national standard of graduation. The implementation impacted the quality of graduates and the quality of education in Indonesia, which is relatively good. At that time, Indonesia sent many teachers to Malaysia, and the Malaysian Government also sent many students to study at various universities in Indonesia.

\section{National Examination as a Paradox}

The national examination is not the most decisive factor and deprives teachers' rights. Teachers have a very wide authority to assess throughout the learning process, from the beginning of the first grade up to the end of the third grade of junior and senior high school. $U N$ is an external assessment to assess the achievement of the Graduates' standards of Competence, as stipulated in Law no. 20 of 2003, on the National Education System (Sisdiknas). In addition, under article 72 paragraph (1) of 
Government Regulation no. 19 The year 2005, on National Education Standards, passing the national examination is only one of the conditions for students to graduate and get a diploma from the school. Three other conditions are completing the entire program, earning a minimum of good grades for religious subjects, having noble characters, having citizenship, having a good personality, aesthetics, physical, sports, and health, and passed the school exams.

For schools that have not been well accredited, the $U N$ must be an option that is considered unfair. Theoretically proper schools good accreditation will practically have a myriad of standardized prerequisites. That is; teachers who are competent in their field, reliable school management, relevant curriculum, facilities, and infrastructure, as well as other requirements that make up a good school. So, what about schools that do not have these criteria with incompetent teachers, no supporting media, an incomplete curriculum, even ironically, schools far from access to information and urban areas, they have only two or three teachers for the whole classes, from the first grade up to the third grade, both at junior and senior high school level. Where is the effectiveness of the $\mathrm{UN}$, if we confront this phenomenon?

In addition, those who do not agree with the $U N$ argue that the implementation of the $U N$ is a waste. Government's funds used for the benefit of the $U N$ reached Rp. 250.000.000.000 (two hundred and fifty billion Rupias). However, if the funds are allocated for other educational purposes, such as teacher training education, management training for headmasters, and improvement of facilities and infrastructure, it might get better.

\section{The Direction of National Education Policy}

After the implementation of the $U N$ within a few years, we know that at least the $U N$ has a major influence on improving the quality of education in Indonesia, the continuity can be said to have given birth to some directions of national education policy itself. Among the policy directions affected by the implementation of the UN were the birth of the National Standard School Examination (USBN), the curriculum change from KTSP into K13, and the implementation of Full Day School (FDS).

It is undeniable that the birth of $U S B N$ as an integration of the school's final evaluation system is a pattern that is structured to strengthen the $U N$ itself. Where the 
$U N$ has been considered by some groups as an unfair system, at least it can be answered with the fulfillment of school-based assessment techniques but follow the national standard. USBN is an act of measuring the learners' achievement and competence conducted by educational unit by referring to the competency standard of graduates to gain recognition of the learning achievement. The legal product is in the Regulation of the Ministry of Education (Permendikbud) No. 4 the year 2018 on assessment of learning outcomes. The direction of national education in the implementation of USBN has been running in recent years, the researcher views this as a national education policy. Through the $U S B N$, teachers will be instrumental in the evaluation of the final phase of the school, especially the development of test instruments which is conducted by a group of appointed teachers.

In addition to $U S B N$, the direction of national education policy affected by the implementation of the $U N$ is the implementation of Curriculum 13. Curriculum 13 or abbreviated as K13 is a curriculum applicable to the current Indonesian Education System. This curriculum is a replacement curriculum of the Curriculum 2006 or KTSP curriculum, which has been valid for approximately 6 years. The 2013 curriculum entered into its probationary years in 2013 by making some schools into stub schools.

In the 2013/2014 academic year, precisely around mid-2013, the Curriculum 2013 is limited to pioneer schools, namely in the first and fourth grade of elementary school, seventh grade of junior high school, and the tenth grade of senior high school or vocational school, while in 2014, the Curriculum 2013 has been applied in the first, second, fourth, and fifth grade of elementary school, seventh and eighth grade of junior high school, and the tenth and eleventh grade of senior high school. The number of schools that became pioneer schools was 6,326 schools spread across provinces in Indonesia.

The 2013 curriculum has four aspects of assessment, namely the aspects of knowledge, skills, attitude, and behavior. In the Curriculum 2013, especially in learning materials, there are streamlined material and additional material. The streamlined material is in Bahasa Indonesia, Socials, KDP, etc., while the additional material is Mathematics. This K13 implementation aims to improve the quality of learning in schools, especially in the context of learners' individual quality in terms of knowledge, skills, attitudes, and behavior. This is very much in line with the first goal of the $U N$ for 
the purpose of improving the quality of education in Indonesia. The legal product of the implementation of $K 13$ is contained in the Regulation of the Ministry of Education (Permendikbud) No. 81A, 2013 on the Implementation of Curriculum 2013.

The direction of the next national education policy, which was born from the implementation of the $U N$ is the implementation of Full Day School. Full Day School (FDS) is an educational program launched by the government in order to maximize school activities. FDS is an all-day school or teaching and learning process that is enforced from the morning until late afternoon, starting at 06.45-15.30 WIB, with recess every two hours. In this case, schools can arrange schedules freely, tailored to the subject's weight and supplemented by the comprehension of the material. "The main thing in full-day school according to (Baharuddin, 2010) is setting the subject schedule and comprehension.

Different views expressed by (Basuki, 2013) regarding Full Day School: schools whose times used for informal learning programs, not rigid, fun for students, and require creativity and innovation from teachers. In this case, it refers to a study which states that the effective learning time for a child is only 3-4 hours a day in a formal setting and 7-8 hours a day in an informal atmosphere.

While (Sulistyaningsih, 2008) states that this Full Day School lasted almost a day full length, i.e. from 08.00 am to $15: 00 \mathrm{pm}$. Thus, the full day school system is a well-organized and well-structured component to support the process of human maturation (learners) through longer and longer school teaching and training efforts compared to the schools in general.

The implementation of FDS is one alternative in overcoming the emergence of various problems of education, both in terms of achievement and in terms of morals. With the FDS program, parents can anticipate, prevent and neutralize the possibility of negative child activity. Full day school also provides a strong foundation in learning in all aspects, namely intellectual, physical, social, and emotional development. Because in this system the school has a much longer time, so the process of teaching and learning becomes better, not only on the delivery of theory but also the practice that gets the proportional time so that science becomes more applicable. Full day school is the basic concept of integrated activity and Integrated Curriculum which distinguishes the school in general. In FDS, all the programs and activities in school, whether playing, studying, 
and worshiping are packed in an education system. The legal foundation that covers the FDS is the Regulation of the Ministry of Education (Permendikbud) No. 23 of 2017, on Full Day School.

\section{CONCLUSIONS AND SUGGESTIONS}

The implementation of the $U N$ is one manifestation of the implementation of Article 58 paragraph (2) of the National Education System Law which is the evaluation of learners, especially the evaluation of students' learning outcomes by independent institutions as an external evaluation to assess the achievement of national education standards, especially the achievement of graduates' competency by the students individually or collectively (on average) at the educational, regional and national level.

The concerns of failing need to be addressed fairly by all parties, especially schools by paying attention to the learning process. If efforts to improve the learning process are done, there is nothing to worry about because all the exam materials have been referring to the applicable curriculum. The improvement of other instruments such as competent teachers, good learning atmosphere, and adequate learning media is also required.

The weaknesses in the implementation of the $U N$ need to be identified and used as an input in improving the implementation of the $U N$ in the future, as a framework to provide accurate information for educational development, especially equity and improvement of primary and secondary education quality. However, after the implementation of the $U N$ in a few years, we know at least the $U N$ has a major impact on improving the quality of education in Indonesia, which sustainability can be said to have given birth to some directions of national education policy itself. Among the policy directions affected by the implementation of the $U N$ were the birth of the National Standard School Examination $(U S B N)$, the curriculum change from KTSP into K13, and the implementation of Full Day School (FDS). 


\section{REFERENCES}

Arikunto, S. (2002). Prosedur Penelitian Suatu Pendekatan Praktik. Jakarta: PT Rineka Cipta.

Asiah, S., \& Rofieq, A. (2011). Analisis Kebijakan Ujian Nasional Tingkat Sekolah Menengah Kejuruan(SMK). Edukasi, 3(1), 75-92.

Baharuddin. (2010). Pendidikan dan Psikologi Perkembangan. Jogjakarta: Ar-Ruzz Media.

Basuki, S. (2013). Fullday School, Harus Proporsional Sesuai Jenjang dan Jenis Sekolah. Retrieved from Smkn1lmj.sch.id/dl/fuldyaschool.pdf.

Buchori, M. (2006). Evaluasi Pendidikan Konsep dan Aplikasi. Uhamka Press.

Delors, J. (2013). Learning The Treasure Within. , 2013. Unesco Publishing.

Dye, T. R. (1978). Understanding Public Policy. Englewood Cliffs. New Jersey: Prentice Hall.

Firmantyo, T., \& Alsa, A. (2016). Integritas Akademik dan Kecemasan Akademik dalam Menghadapi Ujian Nasional pada Siswa. PSIKOHUMANIORA: Jurnal Penelitian Psikologi, 1(1), 1-11.

Ghofur, A. (2014). Mereposisi Mainstream dan Dampak Psikologi Ujian Nasional. Jurnal Ilmu Sosial Dan Humaniora, 1(1), 34-41.

Hayat, B. (2006). Assesment Berbasis Kelas. Puspendik Balitbang.

Hidayah, N. (2013). Ujian Nasional Dalam Perspektif Kebijakan Publik. Jurnal Pencerahan, 7(1), 35-40.

Hofferbert, R. I. (1974). The Study of Public Policy. Indianapolis: Bobbs-Merrill.

Jamaris, M. (2010). Orientasi Baru dalam Psikologi Pendidikan. Yayasan Penamas Murni.

Mardapi, D. (2009). Evaluasi Penerapan Ujian Akhir Sekolah Dasar Berbasis Standar Nasional. Jurnal Penelitian Dan Evaluasi Pendidikan, 13(6), 227-245.

Nasution, M. K. M. (2016). Menggali Potensi Ujian Nasional.

Safari. (2015). Ujian Nasional Sebagai Cermin Mutu Pendidikan dan Pemersatu Bangsa. Jurnal Pendidikan Dan Kebudayaan, 21(2), 101-114.

Silverius, S. (2010). Kontroversi Ujian Nasional Sepanjang Masa. Jurnal Pendidikan Dan Kebudayaan, 16(2), 194-205.

Soedijarto. (2000). Pendidikan Nasional sebagai Wahana Mencerdaskan Kehidupan Bangsa dan Membangun Peradaban Negara-Bangsa. CINAPS.

Soedijarto. (2008). Landasan dan Arah Pendidikan Nasional Kita. Kompas. 
Sudijono, A. (2005). Pengantar Evaluasi Pendidikan. Raja Grafindo Persada.

Sudjana, N. (2005). Penilaian Hasil Proses Belajar Mengajar. Rosdakarya.

Sulistyaningsih, W. (2008). Full Day School dan Optimalisasi Perkembangan Anak. Yogyakarta: Paradigma Indonesia.

Sulistyo, G. H. (2007). Ujian Nasional (UN): Harapan, Tantangan, dan Peluang. WACANA, 9(1), 79-106.

Supa'at. (2013). Madrasah dan Ujian Nasional. Jurnal Nadwa: Jurnal Pendidikan Islam, 7(2).

Surapranata, S. (2004). Panduan Tes Tertulis; Implementasi Kurikulum 2004. Bandung: Rosdakarya.

Suwandi. (2013). Evaluasi Pelaksanaan Ujian Akhir Sekolah Berstandar Nasional (UASBN). Jurnal Pendidikan Teknologi Dan Kejuruan, 21(3).

Syafaruddin. (2008). Efektivitas Kebijakan Pendidikan. Rineka Cipta.

Tayibnapis, F. Y. (2000). Evaluasi Program. Rineka Cipta.

Tilaar. (2009). Kekuasaan dan Pendidikan. Rineka Cipta.

Wirawan. (2004). Profesi dan Standar Evaluasi. Uhamka Press.

Zakaria, T. R. (2004). Pendekatan-Pendekatan Pendidikan Nilai Dan Implementasi dalam Pendidikan Budi Pekerti. Jurnal Pendidikan Dan Kebudayaan, 6(26). 